\title{
Cobweb pattern of pseudoexfoliation in the capsular bag-intraocular lens complex
}

\author{
Sharmila Rajendrababu, ${ }^{1}$ Vijayalakshmi A Senthilkumar, ${ }^{1}$ Sagnik Sen (1) ${ }^{2}$
}

${ }^{1}$ Department of Glaucoma, Aravind Eye Hospital, Madurai, Tamil Nadu, India ${ }^{2}$ Department of Vitreo-retina, Aravind Eye Hospital, Madurai, Tamil Nadu, India

\section{Correspondence to Dr Sagnik Sen; riksag@gmail.com}

Accepted 24 August 2020

\section{DESCRIPTION}

Pseudoexfoliation (PXF) syndrome is an age-related systemic disease having ocular manifestations characterised by deposition of a white fluffy amyloidlike proteinaceous material in the eye.

A 73-year elderly man, a known case of PXF glaucoma, who underwent combined trabeculectomy with posterior chamber intraocular lens (PCIOL) implantation in the right eye (OD) 6 years ago came for regular ophthalmic check-up. His best-corrected visual acuity (BCVA) and intraocular pressure (IOP) OD were 20/40 and $18 \mathrm{~mm} \mathrm{Hg}$ respectively. Anterior segment evaluation revealed clear cornea, avascular bleb with surgical iridectomy at 12 o'clock and PXF deposits over the sphincter area with dense strands of PXF deposits in a cobweb pattern occupying the entire capsular bag-PCIOL complex (figure 1A,B). Further, 2 clock hours zonular laxity was noted from 3 to 5 'o clock, which was clinically diagnosed by increased clear space between the posterior surface of the iris and PCIOL. Over the years, the patient is prone to develop severe zonular laxity, capsular phimosis, decentration or dislocation of the lens-bag complex, vitreous prolapse into anterior chamber. As our patient was asymptomatic with BCVA of 20/40, with a functioning filtering bleb with stable IOP, we did not consider a laser or surgical option to remove the PXF material. However we have emphasised on the need for close monitoring for anticipated complications such as late decentration and dislocation.

PXF syndrome was first described by a Finnish ophthalmologist in 1917..$^{1}$ The prevalence of PXF ranges between $6 \%$ and $10 \%$ and its incidence is reported to be more in women and increases with age. ${ }^{2}$ Although PXF is more common in women, men appear to be at greater risk of developing glaucoma. It is also reported to have a familial predisposition.

A high risk of developing PXF is conferred by mutations in the LOX1 gene at the locus $15 \mathrm{q} 22 .{ }^{3}$ It is associated with some vascular disorders such as myocardial infarction, aneurysms of the abdominal aorta, sensorineural hearing loss and Alzheimer disease. ${ }^{4}$ Typical exfoliative material has been found to be deposited in many organs of the body, including the heart, liver, lung, kidneys and meninges, suggesting abnormal connective tissue metabolism. These white deposits are found along the insertions of zonules in ciliary body and lens capsule at equator which causes degeneration and localised autolysis especially at the ciliary body epithelium, thereby creating zonular

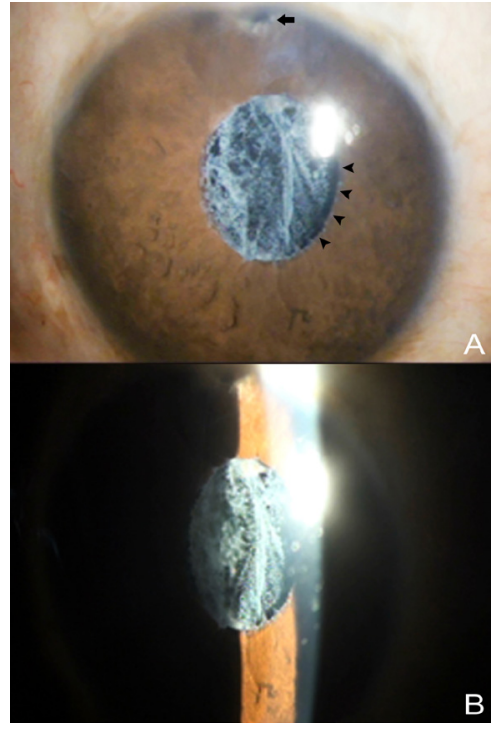

Figure 1 (A) Diffuse illumination photo OD showing surgical iridectomy (black arrow) at 12 o'clock and PXF deposits over sphincter area with dense strands of PXF deposits in the capsular bag-PCIOL complex. 2 clock hours zonular laxity was noted from 3 to 5 o'clock (black arrowheads showing the extent of zonular laxity). (B) Slit image OD showing a cobweb pattern of dense strands of PXF occupying the entire capsular bag-PCIOL complex. PCIOL, posterior chamber intraocular lens; PXF, pseudoexfoliation.

instability. ${ }^{5}$ Further, PXF material blocks spaces in the trabecular meshwork, leading to PXF glaucoma. ${ }^{6}$

\section{Learning points}

Zonular fragility increases the risk of zonular dialysis or vitreous loss up to 10 times in pseudoexfoliation (PXF) individuals and postoperative complications such as posterior capsular opacification, capsule contraction syndrome, intraocular lens (IOL) decentration and inflammation can occur at a higher rate with PXF.

- PXF is a relatively common cause and most identifiable cause of secondary open-angle glaucoma.

- PXF is an important risk factor for late in-thebag IOL subluxation/dislocation, and since PXF is a continuous ongoing age-related disorder, patients need close monitoring to avoid visionthreatening complications. 
Modern phacoemulsification techniques have improved surgical outcome with reduced complications during cataract surgery. However, this advantage is only marginal in PXF owing to poor mydriasis. Dense anterior subcapsular fibrosis may occur in eyes with small rhexis, as there is a greater area of contact between the anterior lens capsule and IOL, causing proliferation and metaplasia of the anterior lens epithelial cells. ${ }^{7}$ One has to aim at an adequate sized rhexis intraoperatively to avoid capsular contraction syndrome by using high molecular weight cohesive viscoelastics and pupil expanding devices. Anterior $\mathrm{Nd}$ :YAG relaxing capsulotomy incisions can be performed when phimosis is first noticed. Surgical correction of dislocation or decentered IOLs must be performed immediately after diagnosis to avoid vision deterioration and complications such as IOL drop to the vitreous, as PXF is a progressive condition. In cases with open-loop and plate-haptic IOLs with dialling holes, without excess residual cortical material or excessive phimosis, repositioning may be safer than exchange if the displaced IOL is noted early enough. ${ }^{7}$

Contributors SR and VAS: conception, data collection, writing and proofing. SS: writing and proofing.

Funding The authors have not declared a specific grant for this research from any funding agency in the public, commercial or not-for-profit sectors.
Competing interests None declared.

Patient consent for publication Obtained.

Provenance and peer review Not commissioned; externally peer reviewed.

\section{ORCID iD}

Sagnik Sen http://orcid.org/0000-0001-5835-5371

\section{REFERENCES}

1 Ritch R, Schlötzer-Schrehardt U. Exfoliation syndrome. Surv Ophthalmol 2001;45:265-315

2 Konstas AGP, Jay JL, Marshall GE, et al. Prevalence, diagnostic features, and response to trabeculectomy in exfoliation glaucoma. Ophthalmology 1993; 100:619-27.

3 Ariga M, Nivean M, Utkarsha P. Pseudoexfoliation syndrome. J Curr Glaucoma Pract 2013:7:118-20

4 Naumann G, Schlötzer-Schrehardt U, Küchle M. Pseudoexfoliation syndrome for the comprehensive ophthalmologist intraocular and systemic manifestationsHistorical image. Ophthalmology 1998;105:951-68.

5 Shingleton BJ, Marvin AC, Heier JS, et al. Pseudoexfoliation: high risk factors for zonule weakness and concurrent vitrectomy during phacoemulsification. Journal of Cataract \& Refractive Surgery 2010;36:1261-9.

6 Ritch R. Exfoliation syndrome-the most common identifiable cause of open-angle glaucoma. J Glaucoma 1994;3:176-7.

7 Liu E, Cole S, Werner L, et al. Pathologic evidence of pseudoexfoliation in cases of in-the-bag intraocular lens subluxation or dislocation. Journal of Cataract \& Refractive Surgery 2015;41:929-35.

Copyright 2020 BMJ Publishing Group. All rights reserved. For permission to reuse any of this content visit

https://www.bmj.com/company/products-services/rights-and-licensing/permissions/

BMJ Case Report Fellows may re-use this article for personal use and teaching without any further permission.

Become a Fellow of BMJ Case Reports today and you can:

- Submit as many cases as you like

- Enjoy fast sympathetic peer review and rapid publication of accepted articles

- Access all the published articles

Re-use any of the published material for personal use and teaching without further permission

\section{Customer Service}

If you have any further queries about your subscription, please contact our customer services team on +44 (0) 2071111105 or via email at support@bmj.com.

Visit casereports.bmj.com for more articles like this and to become a Fellow 